Jarosław JAKIELASZEK

(Warszawa, UW)

\title{
STRATEGIE TEKSTOWE APOLOGETYKI CHRZEŚCIJAŃSKIEJ (Tertulian, Apologetyk 16)
}

Tradycyjna opinio communis na temat użycia czasów w consecutio temporum u Tertuliana uznaje zasadniczo zgodność uzusu językowego autora Apologetyku z normą klasyczną, dopuszczając równocześnie odstępstwa uzasadniane diachroniczną zmianą językową i językowo-stylistycznym charakterem tekstów. Klasycznym przykładem na taki pogląd jest opinia wyrażona przez Hoppego: „użycie czasów gramatycznych u Tertuliana jest zasadniczo czysto łacińskie i nie tak błędne, jak należałoby w jego czasach oczekiwać" ". Jeśli oddzielić od tego sądu elementy wartościujące, których występowanie w analizach tekstów poklasycznych, jakkolwiek silnie zakorzenione w normatywnie ufundowanej tradycji opisowej, nie znajduje merytorycznego uzasadnienia, opinia ta sprowadza się do konstatacji stabilności consecutio temporum. Hoppe słusznie odrzuca zarówno pogląd o istotnej rozbieżności między uzusem Tertuliana i stanem klasycznym, jak i teorię wpływu języków semickich na Latinitas autorów chrześcijańskich działających w Afryce. Z drugiej jednak strony, szereg passusów uznaje za właściwe wyjaśnić przez odwołanie do brewilokwencji Tertuliana. Chociaż lapidarność wypowiedzi, skutkująca często śmiałymi brachylogiami, może być słusznie uważana za jedną z charakterystycznych cech stylu autora De pallio, przyjęcie jej za podstawę wyjaśnienia zjawiska składniowego wymaga mocnej podstawy faktycznej. W przytaczanych przezeń w związku z consecutio temporum przykładach nie znajduje ona uzasadnienia, choć na pozór wydaje się niezbędna dla wyjaśnienia kształtu wypowiedzi Tertuliana.

Metodę Hoppego może ilustrować następujący fragment:

„Haec ex abundanti, ne quid rumoris irrepercussum quasi de conscientia praeterissemus" ${ }^{2}$.

\footnotetext{
${ }^{1}$ H. Hoppe, Syntax und Stil des Tertullian, Leipzig 1903, 69.

2 Tertullianus, Apologeticus 16, 14, CCL 1, 117.
} 
Hoppe $^{3}$ analizuje zdanie jako rezultat brachylogii, tłumacząc zdanie „ne praeterissemus” jako „ne praeterisse videamur”. Podobną strategię przyjmuje także wobec szeregu innych miejsc:

„Margarita namque, vel ipso nomine pretiosa, dehausit, credo ne mendicius patre coenasset" .

„Enimvero, qui utique interdum cogitabant, unde cecidissent, et post libidinum vaporata momenta caelum suspirabant, illi id ipsum bonum feminarium naturalis decoris, ut causam mali, sic remuneraverunt; ne ei scilicet profuisset felicitas sua, sed ut devectum de simplicitate et sinceritate una cum ipsis in offensam Dei perveniret" .

„Ut autem tantum sigillarium extrinsecus quoque inornassent, satellites ei angelos proferunt, par genus; si inter se, potest fieri, si vero soteri consubstantivos, ambigue enim positum inveni - quae erit eminentia eius inter satellites coaequales?" 6 .

„Exigeretur enim id quoque evangelium, quod Paulus invenit, cui fidem dedit, cui mox suum congruere gestiit, siquidem propterea Hierosolymam ascendit ad cognoscendos apostolos et consultandos, ne forte in vacuum cucurrisset, id est ne non secundum illos credidisset et non secundum illos evangelizaret" ${ }^{\text {" }}$.

W istocie jednak przytoczone fragmenty nie wymagają tak sztucznego wyjaśnienia, a ich pozorna niezwykłość jest jedynie rezultatem rzadkości występowania analogicznych struktur, a nie zastosowania brachylogii.

Brak izomorfizmu między własnościami semantycznymi i ich morfologicznymi wykładnikami nie jest cechą w praktyce latynistycznej powszechnie akceptowaną (w przeciwieństwie do semantyki leksykalnej), zarówno w odniesieniu do kategorii nominalnych, jak i werbalnych. Szczegółowe analizy wykazują jednak dobitnie nieprzejrzystość morfologii i brak zasadności teorii opartych na założeniu o ,podstawowym znaczeniu” w zakresie kategorii przypadka lub czasu ${ }^{8}$. W istocie fakt ten akceptuje także tradycyjna gramatyka opisowa, ujmując consecutio temporum w kategoriach równoczesności (lub uprzedniości albo następczości) czynności wyrażanych przez konstrukcje bezokolicznikowe lub zdania z formą finitywną w koniunktiwie, dostrzegając zatem ekwiwalencję semantyczną (w odniesieniu do własności temporalnych) a.c.i. i koniunktiwu, mimo oczywistej różnicy w budowie morfologicznej. W szczególności, znajduje w ten sposób wyraz podstawowa właściwość zdań podrzędnych podlegających consecutio, tj. brak semantycznej specyfikacji własności temporalnych. Jeśli za

\footnotetext{
${ }^{3}$ Por. Hoppe, Syntax und Stil, s. 70.

4 Tertullianus, De pallio 5, 7, CCL 2, 750.

5 Tertullianus, De cultu feminarum I 2, 4, CCL 1, 345.

6 Tertullianus, Adversus Valentinianos 12, 5, CCL 2, 764.

7 Tertullianus, Adversus Marcionem IV 2, 5, CCL 1, 548.

${ }^{8}$ Por. H. Pinkster, Latin syntax and semantics, London 1990.
} 
punkt wyjścia przyjąć pronominalną teorię czasów à la Kratzer i Heimª , podstawowy zasób cech semantycznych tworzących specyfikację temporalną obejmuje dwa czasy (teraźniejszy i przeszły, lokalizujące interwał odniesienia w stosunku do interwału wypowiedzi) oraz trzy podstawowe aspekty (imperfektywny, perfektywny i uprzedni, lokalizujące interwał temporalizowanego zdarzenia w stosunku do interwału odniesienia; dwa pierwsze obejmują relację inkluzji między obu interwałami, aspekt uprzedni zaś wyraża ściśle liniową relację uprzedniości) ${ }^{10}$. Aspekty rozumiane są zatem zasadniczo zgodnie $\mathrm{z}$ analizą Kleina ${ }^{11}$ (zatem odmiennie od tradycji slawistycznej). Oba składniki łączą się z atemporalną formą czasownikową, określoną jedynie co do opisywanego typu sytuacji, rozumianego zgodnie $\mathrm{z}$ tradycją wywodzącą się $\mathrm{z}$ analiz Vendlera $^{12}$. Obok wyżej wymienionych elementów, konieczne jest też niekiedy wprowadzenie dodatkowych operatorów (modalnych lub aspektowych).

Analiza consecutio temporum w tak ujętych ramach prowadzi do konkluzji niedopuszczalności swobodnych wystąpień wyróżnionej zmiennej czasowej w kontekstach mocno intensjonalnych, tj. w szczególności w zawisłości od verba dicendi etc. W kontekstach takich występowanie a.c.i., tj. struktury z atemporalną formą czasownikową, czyni ten zakaz widocznym także morfologicznie:

„Ego me scio neque alia carne adulteria commisisse neque nunc alia carne ad continentiam eniti" 13

Verbum regens scio analizować należy jako realizujące kompleks semantyczny czas teraźniejszy + semantyczny aspekt imperfektywny; pierwsze a.c.i. zawiera

${ }^{9}$ Por. m.in. D. Abusch, On verbs and time, diss., Massachusetts Amherst 1985; A. von Stechow, Tense in intensional contexts: two semantic accounts of Abusch's theory of tense, Tübingen 1995; D. Abusch, On the temporal composition of infinitives, w: J. Guéron - J. Lecarme (ed.), The syntax of time, Cambridge Mass. 2004; 27-54, A. Kratzer, More structural analogies between pronouns and tenses, w: D. Strolovich - A. Lawson (ed.), Proceedings of SALT VIII, Ithaca NY 1998, 92-110; A. von Stechow, On the proper treatment of tense, New York 1995, A. von Stechow, The Janus face of aspect. Handout from talk given in Milan, Milano 2001; E. Gerö - A. von Stechow, Tense in time: the greek perfect, w: R. Eckardt - K. von Heusinger - C. Schwarze (ed.), Words in time: diachronic semantics from different points of view, Berlin - New York 2003, 251-294; K. Kusumoto, Tense in embedded contexts, diss., Massachusetts Amherst 1999.

${ }^{10}$ Warto zwrócić uwagę, że - w przeciwieństwie do klasycznego ujęcia w tradycji Montague’a - czasy nie są analizowane jako operatory. Wyróżniona zmienna czasowa jest interpretowana jako odnosząca się do czasu lokalnego (dla uproszczenia pomijamy relatywizowanie interpretacji w stosunku do kontekstu). Z zasobu czasów semantycznych wyłączony został także czas przyszły (za Abusch analizowany jako składający się z odpowiedniego czasu semantycznego i operatora modalnego).

${ }^{11}$ Por. W. Klein, Time in language, London - New York 1994.

12 Tj. stany, czynności etc., por. Z. Vendler, Linguistics in philosophy, Ithaca 1967, a także przegląd klasyfikacji w odniesieniu do czasownika w języku polskim, np. R. Grzegorczykowa i in., Gramatyka wspótczesnego języka polskiego. Morfologia. Warszawa 1999, 152nn.

13 Tertullianus, De resurrectione carnis 59, 3, CCL 2, 1007. 
formę infinitiwu perfecti, tj. zawierającą semantyczny aspekt (bez semantycznego czasu!) uprzedni; drugie a.c.i. - infinitivus praesentis, którego morfologia jest wykładnikiem semantycznego aspektu imperfektywnego. Wyróżniona zmienna czasowa w zdaniu głównym jest interpretowana jako odnosząca się do czasu wypowiedzi; nie występuje ona natomiast swobodnie w strukturze bezokolicznikowej, dzięki czemu forma niefinitywna nie jest interpretowana bezpośrednio w stosunku do czasu wypowiedzi - w istocie a.c.i. jest konstrukcją atemporalną, wyposażoną jedynie w informacje aspektowe, prawidłowo lokujące sytuację wyrażoną przez czasownik w stosunku do zdarzenia wyrażonego przez verbum regens (niezależnie od formy czasowej tego ostatniego). Identyczną strukturę należy przypisać zdaniom z quod (quia) zastępującym konstrukcje bezokolicznikowe w łacinie poklasycznej:

„Annon scitis, quod Deus sit omnium dominus?"14.

„Dicunt enim Iudaei, quod a primordio sanctificaverit Deus diem septimum”.15.

W tych jednak przypadkach czasownik w zdaniu podrzędnym występuje w formie finitywnej, wymagającej obecności morfologii czasowej. Jej rodzaj jest regulowany przez consecutio temporum, przede wszystkim przez semantyczny czas verbum regens (oraz aspekt w przypadku aspektu uprzedniego), skąd zarówno zmiany morfologii czasownika bez zmiany interpretacji czasowej zdania podrzędnego, jak i różnorodność zachowania niektórych form czasownikowych (por. consecutio po perfectum, zależną od jego semantycznych właściwości). Podkreślić należy, że reguły te odnoszą się do ściśle określonej grupy struktur, obejmującej zdania w pozycji argumentowej (tzw. zdania dopełnieniowe oraz wyodrębniane tradycyjnie jako osobna grupa zdania pytajne zawisłe) oraz zdania celowe ${ }^{16}$; w pozostałych kontekstach swobodne wystąienie wyróżnionej zmiennej czasowej nie jest wykluczone.

Synchroniczna nieprzejrzystość morfologii w stosunku do semantycznej budowy form werbalnych dobrze widoczna jest w przypadku form tworzonych $\mathrm{z}$ tematu perfecti. Dotyczy to nie tylko form indicativus perfecti, ale także form bezokolicznikowych. Jak wiadomo, infinitivus perfecti występuje nie tylko jako realizacja semantycznego aspektu uprzedniego, ale również jako forma zawierająca rezultatywny operator aspektowy. Autorzy okresu klasycznego, zmierzając do ujednolicenia i ujednoznacznienia relacji między morfologią i składnią, w znacznym stopniu eliminują takie zastosowanie infinitiwu perfecti, por. jednak np.:

14 Tertullianus, De fuga in persecutione 3, 2, CCL 2, 1139.

15 Tertullianus, Adversus Iudaeos 4, 1, CCL 2, 1347.

${ }^{16} \mathrm{Na}$ temat możliwych przyczyn włączenia ich do tej grupy, por. C. Boeckx, Islands and chains, Amsterdam - Philadelphia 2003. 
„Tametsi statim vicisse debeo, tamen de meo iure decedam et tibi quod in alia causa non concederem in hac concedam fretus huius innocentia"17.

Słusznie Kühner i Stegmann ${ }^{18}$ interpretują infinitivus perfecti jako semantycznie ekwiwalentny strukturze predykatywnej victor esse, tj. zawierający operator rezultatywny. Podobna sytuacja występuje w przypadku form finitywnych, które jednak wymagają morfologicznego czasu, nabywanego w drodze zastosowania zarysowanego wyżej mechanizmu consecutio. Należy zauważyć, że w zdaniach celowych interpretacja formy coniunctivus perfecti lub plusquamperfecti jako zawierającej semantyczny aspekt uprzedni jest wykluczona ze względu na semantyczne własności ut finale. W przeciwieństwie do ut finale, ut obiectivum nie zawiera operatora modalnego skutkującego w interpretacji czynności zdania podrzędnego jako poźniejszej; coniunctivus perfecti (lub plusquamperfecti) może zatem zawierać semantyczny aspekt uprzedni:

„Sed perturbati dolore animi magnisque meorum iniuriis metuo ne id consili ceperimus quod non facile explicare possimus"19.

„Verebar, ne plane victus essem,20.

Morfologia perfecti lub plusquamperfecti jest tu wykładnikiem semantycznego aspektu uprzedniego, lokalizującego zdarzenie wyrażane przez zdanie podrzędne w uprzedniości do temporalizowanego zdarzenia zdania głównego. W zdaniach celowych interpretacja taka jest niemożliwa; morfologiczne perfectum (resp. plusquamperfectum) musi zatem być wykładnikiem semantycznego aspektu imperfektywnego i operatora rezultatywnego (przy czym różnica sprowadza się jedynie do czasu morfologicznego determinowanego przez consecutio - semantycznie coniunctivus zdania podrzędnego jest atemporalny). Taką właśnie interpretację należy przypisać przytoczonym powyżej przykładom zaczerpniętym z pism Tertuliana. Ani struktura składniowa, ani konfiguracja semantyczna, ani wreszcie ich morfologiczna realizacja nie stanowią odstępstwa od klasycznych zasad consecutio temporum, nie wymagając równocześnie przyjęcia odrębnego wyjaśnienia (jak sugeruje Hoppe). Niezwykłość takich miejsc jest jedynie pozorna, a wrażenie takie jest rezultatem normalizującej tendencji obecnej w prozie klasycznej - nawet tam jednak nie w pełni prowadzącej do izomorfizmu semantyki i morfologii.

17 Cicero, Pro Roscio Amerino 73.

${ }^{18}$ Por. R. Kühner - C. Stegmann, Ausführliche Grammatik der lateinischen Sprache, II/1, Hannover 1912, 135.

19 Cicero, Ad familiares 14, 12.

${ }^{20}$ Rhetorica ad Herennium 4, 65. 


\section{TEXTUAL STRATEGIES OF CHRISTIAN APOLOGETICS} (TERTULLIANUS, APOLOGETICUS 16)

\section{(Summary)}

The paper examines a group of subjunctive clauses attested in Tertullian's works, which seem to deviate from the rules of consecutio temporum. Earlier researchers assumed that the unusual pattern follows from brachylogy, otherwise frequent in Tertullian's writings. It is argued that in fact such clauses obey the rules of the Classical period and there is no need to explain their behaviour as resulting from a brachylogical expression. 